\title{
Assessment of the efficiency of the decisions made during implementation of the investment project in construction
}

\author{
Irina Karakozova ${ }^{1,{ }^{*}}$ and Yulia Prochorova ${ }^{1}$ \\ ${ }^{1}$ Moscow State University of Civil Engineering, 129337, 26, Yaroslavskoye Shosse, Moscow, Russia
}

\begin{abstract}
The imperfection of structure and the maintenance of stages of a predesign stage of implementation of the investment project creates some problems which pass into the subsequent stages of the reproduction cycle of a capital construction project, forming additional expenses of time, money and human resources. The authors pay the main attention to the stage of justification of investments (mainly to the means of the federal budget) as to the key element of decision making on the project implementation and also to the technical-and-economical justification of the project, which determines the further design and construction of the facility of the real estate. It is offered to use the system of indicators for the assessment of efficiency of the made decisions on the basis of uncontrollable and controlled factors. The mathematical model of the factors, the order of definition of the extent of their influence is offered. Scenarios of the choice of the investment decision on the basis of the established principles in the conditions of uncertainty are described. The authors point out, that during introduction of the offered mechanism it is necessary to adopt the relevant amendments to the legislative and regulations of the Russian Federation, that in turn involves the emergence of a temporary log. However, the planned results of the work of the modernized system will affect positively on the reduction of duration of the predesign stage without any loss of its qualitative characteristics. Thus, that might become one of the key factors of sustainable development of modern cities.
\end{abstract}

\section{Introduction}

Social-and-economic living conditions of existence and development city planning in Russia plays an important role in the formation of scientific-and-technical, innovative and lifesupporting capacity of the country. It is obvious that social conditions take the predominating position, as the main criterion of realization of urban policy is now the person, for the benefit of whom real estate objects are not just built, but the favorable environment of activity, which face some requirements (safety, comfort, convenience, accessibility, compliance to needs of inhabitants of this area, environmental friendliness and so on) is formed. The control system of construction industry in the conditions of realization of the new paradigm of "people"

\footnotetext{
${ }^{*}$ Corresponding author: $\underline{i . k a r @ i n b o x . r u}$
} 
represents by and large implementation of priority state programs, with attraction of financial resources of the federal budget. Process of adoption of investment decisions is the integral part of strategic planning which has to provide coordination of long-term goals of the state and the use of the resources, directed to implementation of priority programmes [1].

\section{Materials and Methods}

The relevance of the research subject is caused by the existence of burning issues in the control system of investment process at implementation of the project on construction of the facility of the real estate with the use of budgetary appropriations. Great financial and temporary resources are required for the project implementation. As a result, that means rather difficult costs structure, which includes many items at all stages of the project implementation, from the predesign stage to the stage of elimination of the facility.

In general the project is considered on 4 phases: concept (predesign stage) $\rightarrow$ implementation $\rightarrow$ maintenance $\rightarrow$ elimination. Throughout the life cycle basic function is tracking of two indicators (if the facility under construction $=$ const): the observance of terms of realization of stages of construction and control of expenses according to the formula: "entrance $\rightarrow$ process $\rightarrow$ exit $"$. That means, all the expenses for the entrance and for the exit of each phase of the process are controlled [2].

However it is impossible to argue, that all the problems begin and stop before or the end of performance of works. All the stages of life cycle of a construction facility from concept till elimination are connected with problems of definition of reliable forthcoming expenses and the subsequent performance of work within the established budget and terms.

The greatest deviation on terms and monetary expenses is unconditional occurs at the stage of coordination and the approval of the design and estimate documents and the beginning of construction of the facility of the real estate and at the stage of commissioning of the object as "the realizable chain" joins a large number of intermediaries without whose conclusion realization of a further stage is impossible [3].

The existing scheme of a reproduction cycle of the real estate allocates a predesign stage from the point of view of observance of formal requirements (Figure 1).

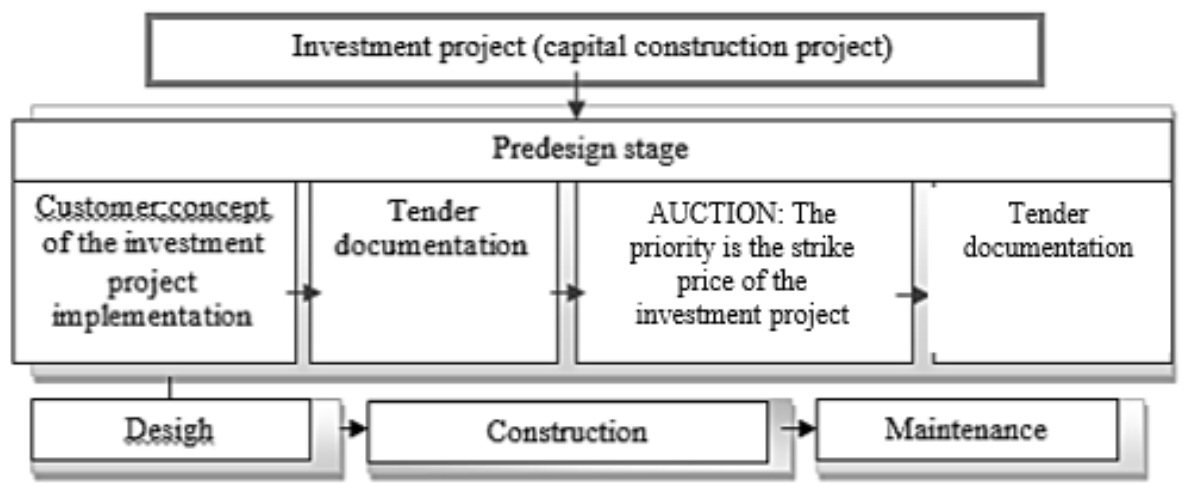

Fig. 1. Reproduction cycle of a real estate facility.

This scheme assumes participation of several off-takers of the project, however, the key factor of success is the posted price, that is preference is given to that builder whose suggested price is lower. Respectively, to submit the project on the auction, potential builders need "to adjust" the project to only one criterion, which is price. During justification projects are divided into 2 groups: 
1. For projects with the cost of realization over 8 billion rubles: during justification of investments qualitative, quantitative criteria and calculation of economic efficiency are considered (the Ministry of Economic Development of Russia: Resolution PRF No. 590) [4];

2. For projects with the cost realization over 1,5 billion rubles: during justification of investments by experts public price and technological audit is booked [5].

Division of projects into groups and also the existing chain of making decisions on implementation of the investment project have caused emergence several problems:

- Duplication of the existing procedures (Justification of economic efficiency according to requirements of the Resolution 590 Public price and technological audit $=$ check of efficiency of the investment project (Resolution PRF 590)) [4];

- Formality of criteria of verification of the investment project and public audit (criteria in the Resolution 590 do not consider differentiation of types of facilifies and requirements, and explicit criterion of public audit are not established at all) [4].

Therefore the purpose of this research is the improvement of process of justification of investments (budgetary appropriations) during implementation of a capital construction project. The concept "justification of investments" is understood as the set of information (relevant, full, reliable, timely), which is necessary for making decision on expediency of attraction of investments (including means of the federal budget) into a capital construction project. This information reflects data on the necessary of creation of a capital construction project, technical equipment and technical opportunities, economic and (or) social efficiency.

For realization of the goal it is necessary to create any new scheme of the reproduction cycle.

\section{Results}

Process of justification of investments, including at attraction of financial resources of the federal budget, has to be modernized with the following provisions:

- the increase in qualitative characteristics of the made investment decisions without creation of additional bureaucratic chains and administrative barriers;

- the increase in informational content in the course of justification of investments by timely study of technical and economic indicators of the project, at observance of all safety requirements depending on functional purpose of an object;

- the creation of system of indicators of assessment of the made investment decisions and also methods of their calculation.

The very process of realization of a facility of capital construction in case of attraction of financial resources of the federal budget (the scheme of a reproduction cycle) has to solve three main tasks during the predesign stage [6]:

1. Expediency of a capital construction project (the functional purpose, the requirements of society solved by this facility, justification of economic and (or) social effect);

2. Determination of exact cost of a capital construction project (justification of absence overestimate and (or) understating of the price of creation of a facility) (The Federal Law 44 "On the contract system in the sphere of purchases of goods, works, services for ensuring the state and municipal needs") [7];

3. Observance of requirements of urban policy, ecology, safety, the general architectural construction (The Federal law No. 39 "About investment activities in the Russian Federation which is carried out in the form of capital investments") $[8,9]$. 


\begin{tabular}{|c|c|c|c|}
\hline \multicolumn{4}{|c|}{ Investment project-Predesign study } \\
\hline Customer (concept) & TENDER & \multirow{2}{*}{$\begin{array}{l}\text { Technical-and- } \\
\text { economical } \\
\text { justification of the } \\
\text { project }\end{array}$} & \multirow{3}{*}{$\begin{array}{l}\text { The project } \\
\text { documentation, } \\
\text { based on technical- } \\
\text { and-economical } \\
\text { justification }\end{array}$} \\
\hline $\begin{array}{l}\text { The state customer } \\
\text { supposes the justification }\end{array}$ & \multirow{3}{*}{$\begin{array}{l}\text { Outline sketch BIM } \\
\text { model (architectural- } \\
\text { and-construction } \\
\text { design); } \\
\text { Explanatory note; } \\
\text { Requirements of } \\
\text { technical regulations; } \\
\text { "Technical solution" } \\
\text { for "exit"; } \\
\text { PROIRITY is the } \\
\text { PROJECT, but not the } \\
\text { strike price. The choice } \\
\text { of the investment } \\
\text { project, which is the } \\
\text { winner. }\end{array}$} & & \\
\hline $\begin{array}{l}\text { decision on the necessity } \\
\text { of creation a real estate }\end{array}$ & & $\begin{array}{l}\text { Statement of the } \\
\text { contract price }\end{array}$ & \\
\hline $\begin{array}{l}\text { 1. Useful effect } \\
\text { (functionality, safety, } \\
\text { price and } \\
\text { technological audit. } \\
\text { 2. Justification of } \\
\text { indicators of economic } \\
\text { efficiency for the } \\
\text { facilities assuming } \\
\text { receiving income. }\end{array}$ & & \multicolumn{2}{|c|}{$\begin{array}{l}\text { Technological justification; Specifications; } \\
\text { System of technical rationing; Territorial } \\
\text { planning (taking into account requirements } \\
\text { of urban policy); Justification of the price } \\
=\text { the fixed "ceiling" price; Justification of } \\
\text { the procedure of connection to engineering } \\
\text { networks; Public discussion; Public price } \\
\text { and technological audit }\end{array}$} \\
\hline \multicolumn{2}{|c|}{ Implementation of the project } & \multicolumn{2}{|c|}{ Statement of the project } \\
\hline Design & Constru & \multicolumn{2}{|c|}{ Maintenance } \\
\hline
\end{tabular}

Fig. 2. Process of justification of investments in the advanced scheme of reproduction cycle of a real estate facility.

During the stage of justification of investments it is recommended to carry out the assessment of efficiency of the made decisions with the use of system of the indicators defining efficiency of adoption of these decisions in relation to a real estate facility. For example, for the assessment of economic efficiency of the made decisions indicators of profit, cost cutting, etc. are estimated. The social efficiency will be confirmed by the exponent of satisfaction of demand of consumers for this real estate facility, and technological efficiency by the use of modern innovative construction technologies, decrease in labor input and terms of construction. The legal efficiency can be estimated by the indicator of safety and legality, and organizational by new forms of interaction of the subjects or optimization existing. You should not exclude also ecological assessment of efficiency of the made decisions by means of calculation of value of an indicator of increase in ecological safety of construction production and construction production or the indicator of security of the project with ecological resources.

At the same time assessment of efficiency can be carried out as with the use of values of quality indicators, and quantitative that will allow to estimate the made decisions and to determine terms of achievement of the goal. It is at the same time necessary to classify factors which will influence efficiency indicators with their division on uncontrollable (exchange rate, the price of resources, etc.) and controlled (the object volume, amount of works, terms, etc.). As any investment decision is made in the conditions of uncertainty, the use of system of indicators and the qualifier of the factors influencing the made decisions will allow to use diversity of decisions for the choice of the most optimal and reasonable solution $[10,11,12$, 13].

Thus, complex accounting of the factors allows to reflect consequences of the investment project, that is expediency of its realization. Naturally, in mathematical model of accounting factors the predominating position is taken by accounting of the time factor, as so called planned "efficiency" is distributed in time. However, for objectives of this research, the 
mathematical model is based on the factors of completeness of information (at respect for the main properties of information: relevance and reliability) and risk factors (uncertainty).

Accounting of risk factor assumes the creation of model with various scenarios of the choice of an optimal solution [14]. The mathematical model is presented in the table 1 .

Table 1. Mathematical model of factors accounting.

\begin{tabular}{|c|c|c|c|}
\hline \#\# & $\begin{array}{l}\text { The stage name } \\
\text { (criteria } \\
\text { estimated) }\end{array}$ & Mathematical formula & Substantial characteristic \\
\hline 1. & Effect indicators & $\begin{array}{c}E f f=\left\{E_{1}, E_{2} \ldots E_{n}\right\} \\
\text { where, } E_{1}, E_{2} \ldots E_{n}- \\
\text { quantitative effect indicators }\end{array}$ & $\begin{array}{c}\text { Indicators: economic, social, } \\
\text { technological, legal, organizational, } \\
\text { ecological efficiency }\end{array}$ \\
\hline 2. & Effect factors & $\begin{array}{c}F=\left\{F_{1}, F_{2} \ldots F_{n}\right\} \\
\text { where, } F_{1}, F_{2} \ldots F_{n}-\text { risk factors }\end{array}$ & $\begin{array}{l}\text { Set of the factors influencing the } \\
\text { chosen indicators of "efficiency" }\end{array}$ \\
\hline 2.1 & $\begin{array}{l}\text { Controlled effect } \\
\text { factors }\end{array}$ & $\begin{array}{l}\qquad X^{t}=\left\{x_{1}, x_{2} \ldots x_{n}\right\} \\
\text { where, } x_{1}, x_{2} \ldots x_{n}-\text { controlled } \\
\text { factors for the forecast period } \mathrm{t}\end{array}$ & $\begin{array}{l}\text { Endogenous factors of the } \\
\text { investment project }\end{array}$ \\
\hline 2.2 & $\begin{array}{l}\text { Uncontrollable } \\
\text { effect factors }\end{array}$ & $\begin{array}{c}Y^{t}=\left\{y_{1}, y_{2} \ldots y_{n}\right\} \\
\text { where, } y_{1}, y_{2} \ldots y_{n}- \\
\text { uncontrollable factors for the } \\
\text { forecast period } \mathrm{t}\end{array}$ & $\begin{array}{l}\text { Exogenous factors of the } \\
\text { investment project }\end{array}$ \\
\hline 3. & $\begin{array}{l}\text { Degree of factors } \\
\text { influence }\end{array}$ & 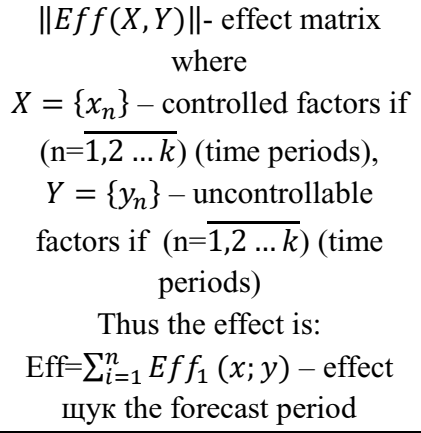 & $\begin{array}{c}\text { Formation of aT effect matrix } \\
\text { depending on the operated and } \\
\text { uncontrollable factors for the } \\
\text { predicted period }\end{array}$ \\
\hline 4. & $\begin{array}{l}\text { Scenarios of the } \\
\text { choice of the } \\
\text { investment } \\
\text { decision }\end{array}$ & $\begin{array}{ll}\text { a) } & \text { optimism principle; } \\
\text { b) pessimism principle; } & \text { of } \\
\text { c) } & \text { principle } \\
\text { guaranteed result; } \\
\text { d) } \\
\text { principle } \\
\text { guaranteed } \\
\text { losses;Savage test; } \\
\text { e) } \begin{array}{l}\text { Bailles-Laplace's } \\
\text { criterion }\end{array} \\
\end{array}$ & $\begin{array}{l}\text { Formations of the principles and } \\
\text { criteria of the choice of the } \\
\text { investment decision in the } \\
\text { conditions of uncertainty }\end{array}$ \\
\hline 4.1 . & $\begin{array}{l}\text { Principle of } \\
\text { optimism }\end{array}$ & $E f f=\max _{x \in X} \max _{y \in Y} E f f(x, y)$ & $\begin{array}{l}\text { The upper bound of possible effect } \\
\text { at the best confluence of } \\
\text { uncontrollable factors is defined }\end{array}$ \\
\hline 4.2 . & $\begin{array}{l}\text { Principle of } \\
\text { pessimism }\end{array}$ & $E f f=\min _{x \in X} \min _{y \in Y} E f f(x, y)$ & $\begin{array}{l}\text { The lower bound of possible effect } \\
\text { at the worst confluence of } \\
\text { uncontrollable factors is defined }\end{array}$ \\
\hline 4.3 . & $\begin{array}{l}\text { Principle of the } \\
\text { guaranteed result }\end{array}$ & $E f f=\max _{x \in X} \min _{y \in Y} E f f(x, y)$ & $\begin{array}{l}\text { Strategy completely excludes risk, } \\
\text { under any conditions of } \\
\text { uncontrollable factors the result } \\
\text { can't appear below Eff. }\end{array}$ \\
\hline
\end{tabular}




\begin{tabular}{|c|c|c|c|}
\hline & & & $\begin{array}{l}\text { Application: } \\
\text { the probability of uncontrollable } \\
\text { factors of } \mathrm{Y}^{\wedge} \mathrm{t} \text { is not known; } \\
\text { it is necessary to exclude any risk, } \\
\text { i.e. under no circumstances } \mathrm{Y}^{\wedge} \mathrm{t} \text { not } \\
\text { to assume that the result was less, } \\
\text { than Eff; the decision is } \\
\text { implemented one (or a small } \\
\text { amount) time. } \\
\text { (if the decision is implemented } \\
\text { repeatedly, or one of conditions of } \\
\mathrm{Y}^{\wedge} \mathrm{t} \text { meets more often, then use of } \\
\text { this principle can be inexpedient). }\end{array}$ \\
\hline 4.4. & $\begin{array}{l}\text { Principle of the } \\
\text { guaranteed losses }\end{array}$ & $\begin{array}{c}\widetilde{-E f f} \\
=\min _{x \in X}\left[\max _{y \in Y}\left\{\max _{y \in Y} E f f(x, y)\right.\right. \\
-E f f(x, y)\}] \\
\widetilde{-E f f}-\text { «anti-efficiency» }\end{array}$ & $\begin{array}{l}\text { Losses are etimated comparing } \\
\text { with the best result on columns at } \\
\text { the fixed } X^{\wedge} t \text { value, the matrix of } \\
\text { losses is created. According to the } \\
\text { set of the worst results the best gets } \\
\text { out according to estimated } \\
\text { function, i.e. with the smallest } \\
\text { deviation from the best results. }\end{array}$ \\
\hline 4.5. & $\begin{array}{c}\text { Savage test } \\
\text { (decision theory) }\end{array}$ & 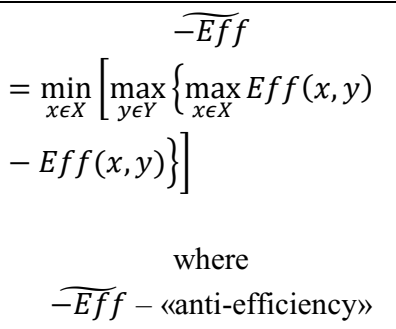 & $\begin{array}{l}\text { Losses are estimated comparing } \\
\text { with the best result on lines at the } \\
\text { fixed } Y^{\wedge} t \text { value, the Savage matrix } \\
\text { is created. According to the set of } \\
\text { the worst results the best gets out } \\
\text { according to estimated function, i.e. } \\
\text { with the smallest deviation from } \\
\text { the best results. }\end{array}$ \\
\hline 4.6. & $\begin{array}{l}\text { Bailles-Laplace's } \\
\text { criterion }\end{array}$ & $\begin{array}{r}E f f=\max _{x \in X}\left[\sum_{i=1}^{m} E f f(x, y)\right. \\
\left.* q_{j}\right] \\
\text { where } q_{j}-\text { possibility of an } \\
\text { external condition } \\
Y^{t} \text { appearance }\end{array}$ & $\begin{array}{c}\text { Probabilities of uncontrollable } \mathrm{Y}^{\wedge} \mathrm{t} \\
\text { factors are known; } \\
\text { risk is allowed; } \\
\text { decision is implemented } \\
\text { repeatedly. }\end{array}$ \\
\hline
\end{tabular}

Realization of this mathematical model increases requirements to quality, relevance and completeness of the information provided, however, the model allows to consider all the variety of controlled and uncontrollable factors of the investment project implementation.

The introduced advanced system of justification of investments into a chain of a reproduction cycle assumes implementation of several mechanisms:

- Gradual refusal of technical and price audit and assessment of efficiency of the attracted budgetary appropriations in favor of justification of investments;

- Gradual transition from budget rationing to the fixed limit indicators of the price of elements (projects, complexes of works, etc.);

- Replacement of the procedure "auction" with the procedure "tender";

- Introduction of phasic design with careful study of the technical-and-economical justification study on the investment project. 


\section{Discussion}

The introduced mechanism of the technical-and-economical justification study and justification of investments assumes obtaining the following results $[14,15,16]$ :

- optimization of planning of capital investments;

- improvement of quality of the project documentation;

- cutting off of inefficient projects at the first steps of implementation of the customer's concept, by granting architectural and construction model and the choice of the project proceeding from the importance and study, but not by the price principle;

- creation of "the frictionless environment" [17, 18];

- justification of investments from the poin of view of justification of the need of creation of a real estate facility;

- study of investment decisions by creation of "a tree of decisions".

\section{Conclusions}

The weaknesses of the existing system of making investment decisions on implementation of a capital construction project were analyzed in the article. The emphasis is put on the attraction and the use of means of the federal budget. The new structure of a predesign stage allowing to develop diversity of decisions is developed.

Nowadays it is necessary to specify legislatively: the study of technical-and-economical justification as justification of investments, the structure and substantial characteristic of the process of justification of investments and also the requirements to the structure and content of this process, the matter of state examination as the mechanism of control of the state of effective use of budget funds. And also the development of the regulatory base, which will create conditions for the transfer to BIM technologies of the state order for construction of the facility of the real estate is necessary. Further information modeling can become an industry standard.

\section{Reference}

1. I. Karakozova, Y. Prokhorova, Economy and Entrepreneurship 4-1(69-1), 747-751 (2016)

2. E. Vasilyeva, I. Polyakova, Economy and Entrepreneurship 4-2 (81-2), 1024-1028 (2017)

3. V. Tatarinov, Russian building complex, http://www.kgexpert.ru/KI-0304-2015.pdf (2015)

4. Decree of the Government of the Russian Federation of October 12, 2008 \# 590, Legislation bulletin of the Russian Federation, 12 (2017)

5. I. Karakozova, Y. Prokhorova, Economy and Entrepreneurship 3-2 (56-2), 682-686 (2015)

6. Urban Development Code of the Russian Federation of December 29, http://www.consultant.ru/document/cons_doc_LAW_51040/(2018)

7. Federal Law 44-FZ of April 05, 2013, Legislation bulletin of the Russian Federation, 11 (2018)

8. Federal Law 39-FZ of February 25, 1999, Legislation bulletin of the Russian Federation, 7 (2017) 
9. Order of the Ministry of Economic Development and Trade of the Russian Federation of April 02, 2014 \#199, http://legalacts.ru/doc/prikaz-minekonomrazvitija-rossii-ot02042014-n-199/ (2018)

10. D. Karnilov, Financing and crediting 13 (151), $54-57$ (2004)

11. G. Franzen, http://elib.altstu.ru/elib/books/ Files/pa2016_01/pdf/207francen.pdf (2016)

12. Y. Stein., N. Taskaeva., T. Slepkova, Matec Web of Conference 106, 08081 (2016)

13. I. Polyakova, E. Chibisova, Economy and entrepreneurship 5(70), 579-582 (2016)

14. I. Mazur, V. Shapiro, N. Olderogge, A. Zabrodin, Investment and construction engineering (Publishing house Economy, Moscow, 2009)

15. E. Vasilyeva, A. Zlentenkov, O. Suzneva, E. Sapozhnikova, IOP Conference Series: Earth and Environmental Science 90, 12122 (2017)

16. T. Tereshkina, A. Mottaeva, L. Andreeva, T. Larinina, IOP Conference Series: Earth and Environmental Science 19, 012138 (2017)

17. A. Bahauovna, A. Bahauovna, International Journal of Applied Engineering Research 10(23), 43446-43449 (2015)

18. A. Bahauovna, A. Bahauovna, International Journal of Applied Engineering Research 11(9), 6808-6816 (2016) 